\title{
PENGUJIAN DAN ANALISIS KINERJA LAMPU TL LED UNTUK PENCAHAYAAN UMUM
}

\author{
Testing and Analysis of Performance LED Tubular Lamp for General Lighting
}

\author{
Sudirman Palaloi, Eka Nurdiana') dan Ari Wibowo2) \\ 1)Balai Besar Teknologi Konversi Energi - BPPT \\ Gedung 620 Kawasan Puspiptek Serpong, Tangerang Selatan, Indonesia \\ ${ }^{2)}$ Puslitbang Badan Standardisasi Nasional \\ Gedung I BPPT Lantai 12, Jl. MH Thamrin No. 8, Jakarta Pusat, Indonesia \\ Email : palaloi@yahoo.com
}

Diterima: 29 Maret 2018, Direvisi: 13 April 2018, Disetujui: 16 April 2018

\begin{abstract}
Abstrak
Lampu LED tube saat ini mulai banyak digunakan untuk penerangan ruangan pada gedung-gedung perkantoran. Hal ini karena penggunaan lampu LED dinilai lebih hemat karena kinerjanya yang bagus. Dalam penelitian ini, dilakukan pengujian kinerja lampu LED tube dari berbagai merek dengan daya 8-18 Watt. Pengujian dilakukan pada sampel lampu LED tube sejumlah 18 buah lampu dari 6 tipe yang berbeda yang selanjutnya disebut Tipe A, Tipe B, Tipe C, Tipe D, Tipe E dan Tipe F. Metode pengujian yang dilakukan mengacu pada standar SNI IEC/PAS 62612:2013. Pengujian dilakukan dengan menggunakan alat uji Integrating Sphere LMS-9000B. Alat ini mampu mengukur karakteristik kolorimetrik, fotometrik dan elektrikal dari lampu yang diuji. Tujuan dari penelitian ini adalah untuk mengetahui karakteristik kuat cahaya, daya lampu dan efikasi lampu dari berbagai tipe lampu LED yang berada di pasaran. Dari hasil pembahasan kuat cahaya diperoleh bahwa lampu Tipe E dan Tipe F memiliki daya nominal yang sama, tetapi menghasilkan lumen yang jauh berbeda. Daya lampu saat operasi secara umum lebih tinggi dari daya nominal lampu, kecuali untuk Tipe B daya lampu saat operasi lebih rendah dari daya nominalnya. Akan tetapi perbedaan tersebut masih dalam toleransi yaitu kurang dari $15 \%$. Analisis efikasi lampu menunjukkan hasil bahwa efikasi tertinggi pada sampel tersebut sebesar $132 \mathrm{~lm} / \mathrm{Watt}$, sedangkan efikasi terendahnya sebesar $64 \mathrm{~lm} /$ Watt. Lampu Tipe A, Tipe D dan Tipe E memiliki efikasi yang tinggi yaitu di atas $120 \mathrm{~lm} /$ Watt, sedangkan lampu Tipe B, Tipe C dan Tipe F memiliki efikasi di bawah $100 \mathrm{~lm} / \mathrm{Watt}$.
\end{abstract}

Kata kunci : lampu LED tube, kuat cahaya, efikasi, daya lampu.

\section{Abstract}

LED tube lamps are now widely used for room lighting in office buildings because LED lights more efficient and good in performance. In this research, LED tube lamp with various brands ranging 8-18 Watt power have been tested. Tests performed on 18 samples of LED lamp from 6 different types, called Type A, Type B, Type C, Type $D$, Type $E$ and Type $F$. The test procedure on this research based on SNI IEC/PAS 62612:2013. Testing process use LMS-9000B Sphere Integration test tool. This tool can measure the colorimetric, photometric and electrical characteristics of the lamps. The purpose of this research is to know the characteristics of lumen, power and efficacy of various types of LED lights that are in the market. From the test results and discussion, Type E and Type F LED lamps have the same nominal power, but produces a much different lumen. Generally, the operation power of lamps are higher than the nominal power of the lamps, except for Type B, power when operating lower than its nominal power. This difference on normal condition must be less than $15 \%$. The efficacy measurement shows that the highest efficacy of the lamp samples was $132 \mathrm{Im} /$ Watt, while the lowest efficacy was $64 \mathrm{Im} /$ Watt. Type A, Type D and Type E efficacy reach above $120 \mathrm{~lm} /$ Watt, while Type B, Type $C$ and Type F efficacy were below $100 \mathrm{~lm} /$ Watt.

Keywords: LED lamp, luminous flux, efication, power.

\section{PENDAHULUAN}

Sistem penerangan merupakan suatu kebutuhan listrik mendasar bagi masyarakat, sebagai sumber penerangan, lampu membantu masyarakat dalam menjalankan aktivitasnya. Pada tahun 2009, pemanfaatan lampu CFL sebagai lampu hemat energi sangat popular, karena saat itu tingkat efikasi lampu tersebut dapat mencapai 70 lumen/ Watt (Palaloi dkk, 2009). Namun di era modern dengan keterbatasan sumber daya dan energi, lampu tidak hanya sekedar sebagai penerangan saja, yang terpenting memberi efisiensi penggunaan lampu. Penemuan teknologi LED dalam 
pembuatan lampu merupakan suatu revolusi dalam produksi lampu. Penggunaan teknologi LED memberi banyak manfaat antara lain lebih hemat energi, tidak mencemari lingkungan, dan fleksibilitas desain lampu untuk menghasilkan pencahayaan sesuai selera serta umur yang panjang. Hasil pengujian dan penelitian yang telah dilakukan oleh Palaloi dkk (2015) terhadap lampu LED bulb yang dipasarkan di Indonesia menunjukkan bahwa dari 59 sampel yang diuji masih tetap dapat menyala dengan baik walaupun mengalami penuran kuat cahayanya rata-rata sebesar $16,9 \%$ setelah dinyalahkan 6000 jam dari cahaya awal.

Dengan cara ekstrapolasi didapatkan bahwa lampu tersebut mempunyai life time ratarata sekitar 20.500 jam. Sementara itu, hasil penelitian yang telah dilakukan oleh Jiajie dkk (2012) memperlihatkan adanya kecenderungan kuat cahaya sedikit menurun mencapai penyalaan 10.000 jam. Dengan cara ekstrapolasi, didapatkan bahwa kuat cahaya lampu menurun hingga $L_{70}$ akan terjadi pada jam 16.000 s.d 20.000 .

Light Emitting Diode (LED) dipandang sebagai peralatan pencahayaan utama di masa mendatang untuk menggantikan peralatan penerangan tradisional, peralatan lampu LED dengan daya keluaran tinggi berkembang pesat dalam beberapa tahun terakhir. Kinerja LED yang telah menjadi perhatian antara lain efisiensi LED, keandalan, dan fitur peredupan (dimming) (Chang dkk, 2013).

Pada awal perkembangannya, LED mampu menghasilkan kombinasi warna dengan menggabungkan merah, hijau, dan biru atau lebih dikenal dengan RGB. Namun karena sangat sulit untuk mendapatkan warna amber (serupa jingga) yang sebenarnya, maka dibuatlah diode LED yang spesifik bertugas menghasilkan warna tersebut. Berdasarkan studi bersama antara pihak yaitu Japan International Cooperation Agency (JICA) - Direktorat Jenderal Energi Baru Terbarukan dan Konservasi Energi (Ditjen EBTKE), Kementerian Energi dan Sumber Daya Mineral (ESDM) - Badan Pengkajian dan Penerapan Teknologi (BPPT), didapatkan bahwa penggunaan energi untuk sektor rumah tangga dengan kontrak daya 450 VA - 900 VA (Golongan Tarif R1) didominasi oleh penggunaan untuk lampu penerangan 26\% (B2TE, 2012).

Penciptaan produk lampu hemat energi menjadi salah satu langkah nyata untuk mengurangi penggunaan sumber daya listrik. Penggunaan lampu hemat energi dapat dijadikan salah satu alternatif solusi untuk mewujudkan upaya penghematan energi tersebut. Lampu LED adalah lampu saat ini yang efisien (perbandingan daya yang diserap dengan cahaya yang dihasilkan sangat baik) dan ekonomis tinggi jangka panjang dibandingkan lampu pijar dan lampu hemat energi (Stevanus, 2012).

Saat ini, produk LED sedang digunakan untuk mengganti teknologi pencahayaan konvensional. Untuk aplikasi iluminasi umum, LED saat ini menghemat 0,38 terawatthours (TWh) listrik per tahun pada tahun 2010 karena penggantian teknologi incumbent untuk LED. Selain penghematan energi, dalam aplikasi penerangan umum LED mampu memberikan umur pakai yang lebih lama (> 50.000 jam). LED sangat sesuai untuk aplikasi cahaya putih luar ruangan, dan memiliki potensi penghematan energi yang signifikan. Dalam aplikasi outdoor ini, LED telah menghemat total 2.2 TWh listrik pada tahun 2010, dan diperkirakan dapat menghemat listrik sebesar 131 TWh per tahun jika semua pencahayaan di sektor ini diganti dengan LED (Navigant Consulting Inc, 2011). Tujuan dari penelitian ini adalah untuk mengetahui karakteristik kuat cahaya, daya lampu dan efikasi lampu dari berbagai tipe lampu LED yang berada di pasaran.

\section{TINJAUAN PUSTAKA}

\subsection{SNI IEC/PAS 62612:2013, Lampu LED Swa-balast untuk Pelayanan Pencahayaan Umum - Persyaratan Kinerja}

Lampu swa-ballast adalah suatu unit yang tidak dapat dipisahkan tanpa merusak secara permanen, dilengkapi kaki lampu yang digabungkan dengan sumber cahaya dan elemen tambahan yang diperlukan untuk penyalaan dan kestabilan sumber cahaya (SNI 04-6504-2001: Lampu swa-ballast untuk pelayanan pencahayaan umum-persyaratan keselamatan).

SNI IEC/PAS 62612:2013 Lampu LED swa-balast untuk pelayanan pencahayaan umum - Persyaratan kinerja merupakan standar adopsi identik (IDT) dengan metode terjemahan dari IEC/PAS 62612 ed.1.0 (2009-06) : Self-ballasted LED - lamps for general lighting services Performance requirements. Standar ini menjelaskan persyaratan kinerja, metode dan kondisi pengujian yang diperlukan, untuk lampu LED swa-balast dengan suplai tegangan sampai dengan $250 \mathrm{~V}$ untuk penggunaan pencahayaan rumah tangga dan pencahayaan umum, yang memiliki: daya pengenal sampai dengan $60 \mathrm{~W}$; tegangan pengenal sampai dengan $250 \mathrm{~V}$ a.b. atau a.s.; dan kaki lampu sesuai IEC 62560:2011. Standar ini mencakup lampu LED 
yang dimaksudkan menghasilkan cahaya putih berlandaskan LED anorganik.

\subsection{Prinsip Kerja LED}

Energi hijau dan peralatan dengan efisiensi tinggi telah dikembangkan dengan cepat untuk mengurangi masalah pemanasan global. Guna meningkatkan efisiensi peralatan penerangan, LED telah menjadi perhatian dan diadopsi sebagai sumber cahaya. Saat ini, produsen LED telah berhasil merancang LED sebagai indikator bagi banyak perangkat di sistem pencahayaan karena konsumsi energinya yang rendah dan umur pakainya yang panjang (Hao dkk, 2015). LED memiliki efisiensi pencahayaan paling tinggi di antara peralatan pencahayaan lainnya. LED memiliki umur pakai yang lebih lama, respon dinamis lebih cepat, volume yang lebih kecil dan indeks rendering warna yang lebih tinggi. LED banyak digunakan untuk mobil, penerangan dalam ruangan, lampu luar, dan lampu jalan baru-baru ini (Hao dkk, 2015).

Prinsip kerjanya LED hingga dapat menyala adalah ketika arus listrik dc mengalir melalui $\mathrm{P} / \mathrm{N}$ junction pada material semikonductor, aliran elektron bertemu hole dan terjadilah rekombinasi antara muatan positif (hole) dan negatif (elektron), dan pada saat itu dilepaskanlah energi cahaya ketika photon terbentuk. Warna dari cahaya yang terpancar bergantung pada level energi photon yang ditentukan dengan energy gap dari material semikonduktor. Untuk menghasilkan luminasi cahaya yang terang dari sebuah LED, tentu diperlukan energi yang cukup besar. diperkirakan teknologi lampu LED dengan daya sekitar 100 Watt mampu menghasilkan cahaya 10.000 lumens (Palaloi, 2015).

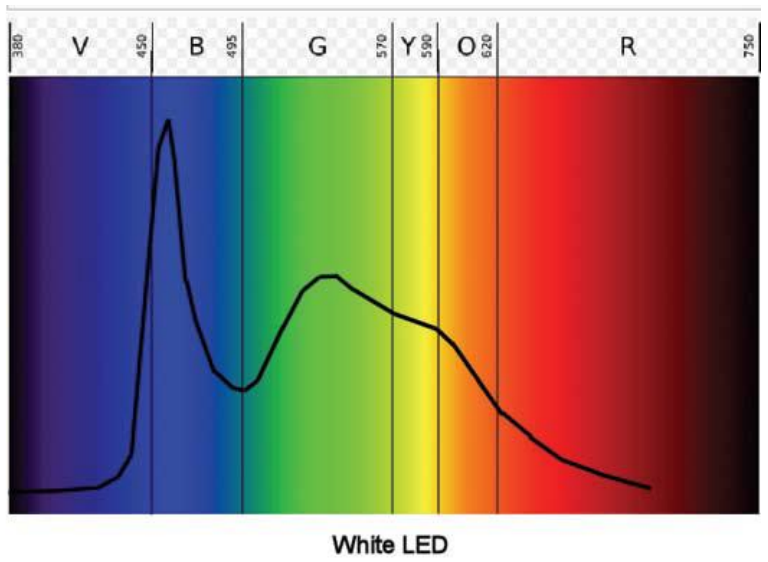

Gambar 1 Spektrum warna pada LED putih.

Perbedaan antara pencahayaan LED dan semua sumber cahaya lainnya adalah panjang gelombang dominan dimana ia memancarkan energi. LED putih sebenarnya adalah LED biru dengan sejumlah kecil fosfor kuning yang dicampur untuk menghasilkan cahaya putih yang tampak. Sehingga lampu LED putih menunjukkan pola bromatik terutama pada pita biru dan hijau. Spektrum warna yang dihasilkan oleh LED putih ditunjukkan pada Gambar 1 (Lincoln, 2012).

Lampu LED memiliki perkembangan efikasi yang pesat dari tahun ke tahun. Efikasi adalah metrik yang digunakan untuk membandingkan keluaran cahaya dengan konsumsi energi, diukur dalam lumen per watt. LED menggunakan energi $50 \%$ sampai $90 \%$ lebih sedikit untuk menghasilkan jumlah cahaya yang sama dengan sumber cahaya tradisional, sehingga lebih menghemat biaya. Perkembangan efikasi lampu LED selama 15 tahun telah mampu melebihi teknologi lampulampu lain yang berkembang lebih dulu, seperti lampu halogen, merkuri, CFL dan flourescent. Grafik perkembangan ini dapat diamati pada Gambar 2 (Lingard, 2012).

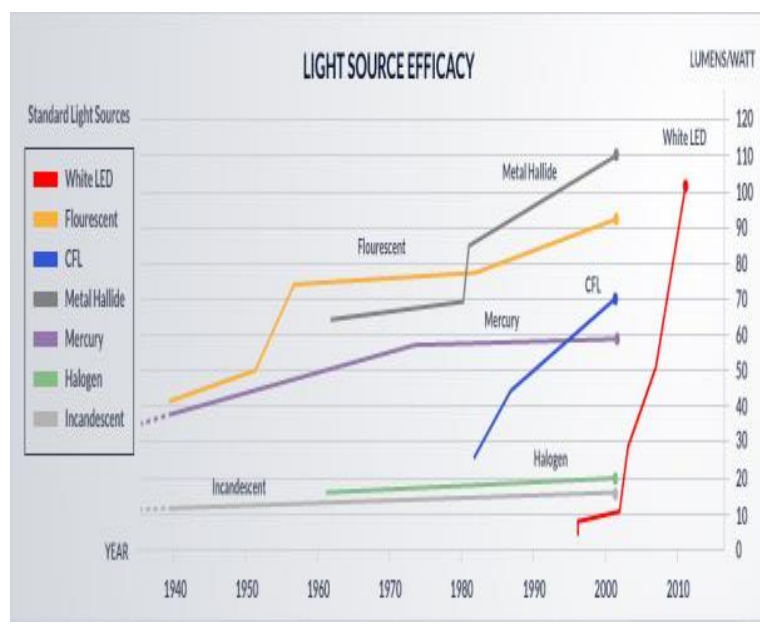

Gambar 2 Perkembangan efikasi lampu pada berbagai teknologi.

Efisiensi energi sumber cahaya biasanya diukur dalam lumen per watt $(\mathrm{Im} / \mathrm{W})$, yang berarti jumlah cahaya yang dihasilkan untuk setiap watt listrik yang dikonsumsi. Parameter ini dikenal sebagai efikasi luminous. Design of Experiment yang telah melakukan penelitian dan pengembangan jangka panjang, memiliki tujuan untuk dapat menciptakan lampu LED putih yang mampu menghasilkan efikasi 160 Im/W yang hemat biaya pada tahun 2025. Sementara itu, LED putih saat ini memiliki efikasi yang paling tinggi dibandingkan dengan peralatan penerangan yang lain (Lingard, 2012). Pada Gambar 3 diperlihatkan lampu LED tube yang beredar dipasaran. 


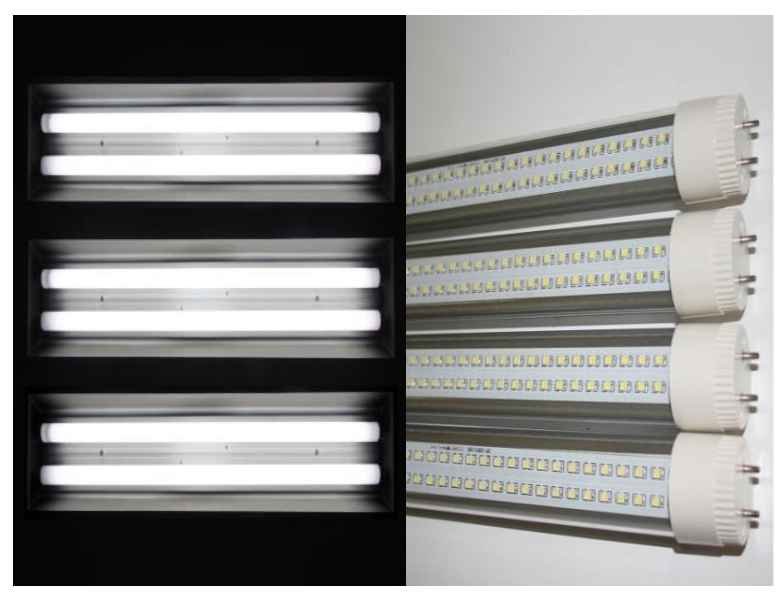

Gambar 3 Lampu TL LED.

Dibalik tingginya efikasi lampu LED, terdapat pula kerugian atau losses yang disebabkan oleh driver lampu LED. Sebagaimana sumber cahaya fluorescent dan high-intensity discharge (HID) yang tidak dapat berfungsi tanpa ballast akan memberikan tegangan awal dan membatasi arus listrik ke lampu.

Tabel 1 Efikasi dari beberapa jenis lampu.

\begin{tabular}{lc}
\hline \multicolumn{1}{c}{ Sumber cahaya } & $\begin{array}{c}\text { Efikasi luminous (Im/W) } \\
\text { (bervariasi tergantung } \\
\text { daya dan tipe lampu) }\end{array}$ \\
\hline $\begin{array}{l}\text { Incandescent (tanpa } \\
\text { ballast) }\end{array}$ & $10-18$ \\
\hline Halogen (tanpa ballast) & $15-20$ \\
\hline $\begin{array}{l}\text { Compact fluorescent } \\
\text { (CFL) (dengan ballast) }\end{array}$ & $35-60$ \\
\hline $\begin{array}{l}\text { Linear fluorescent } \\
\text { (dengan ballast) }\end{array}$ & $50-100$ \\
\hline $\begin{array}{l}\text { Metal halide (dengan } \\
\text { ballast) }\end{array}$ & $50-90$ \\
\hline $\begin{array}{l}\text { Cool white LED }>4000 \\
\text { K (dengan driver) }\end{array}$ & $60-92$ \\
\hline $\begin{array}{l}\text { Warm white LED }<4000 \\
\mathrm{~K} \text { (dengan driver) }\end{array}$ & $27-54$ \\
\hline
\end{tabular}

Demikian pula, LED membutuhkan catu daya yang biasa disebut dengan "driver". Akan tetapi, meskipun ada kerugian yang disebabkan oleh driver LED tersebut, lampu LED tetap memiliki efikasi yang lebih tinggi. Kisaran efikasi dari beberapa jenis lampu ditunjukkan pada Tabel 1 (Palaloi, 2015).

\section{METODE PENELITIAN}

\subsection{Alat Pengujian}

Pengujian ini menggunakan alat Integrating Sphere LMS-9000B yang berfungsi untuk mengukur karakteristik kolorimetrik, fotometrik dan elektrikal dari lampu yang diuji. LMS-9000B dirancang untuk memiliki kemampuan menghasilkan distribusi spektral cahaya tampak, menirukan berbagai sumber cahaya di wilayah yang terlihat oleh kontrol umpan balik dari daya radiasi yang dipancarkan oleh LED secara individual. Sistem uji LED ini dapat digunakan sebagai standar transfer untuk aplikasi fotometrik, kolorimetri dan radiometrik.

Karakteristik kolorimetrik yang dapat diukur antara lain: Chromaticity Coordinates, CCT, Color Ratio, Peak Wavelength, Half Bandwidth, Dominant Wavelength, Color Purity, CRI, dan Spectrum Test. Karakteristik Fotometrik yang dapat diukur antara lain Luminous Flux, Luminous Efficiency, Radiant Power, Pupil Flux, Pupil Flux Efficiency, Pupil Factor, dan Cirtopic Flux. Sedangkan karakteristik Elektrikal yang dapat diukur adalah Tegangan, Arus, Daya, dan Faktor Daya. Skema alat LMS-9000B ditunjukkan oleh Gambar 4 di bawah.
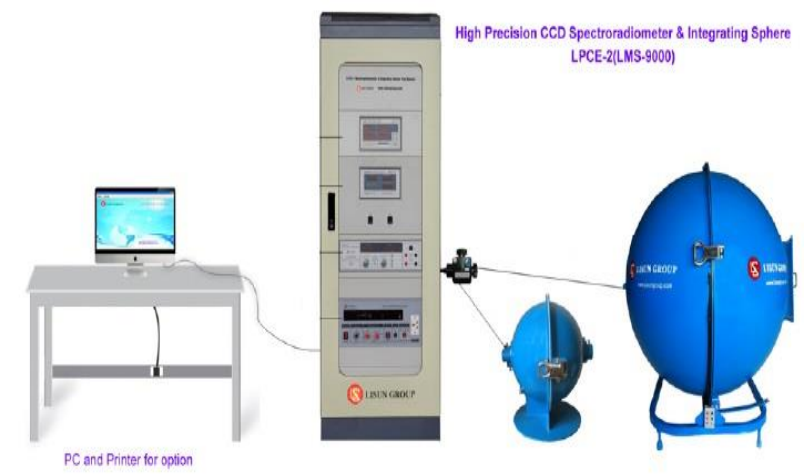

Gambar 4 Skema LMS-9000B untuk uji efikasi

\subsection{Metode Pengujian}

Pada penelitian ini, dilakukan pengujian efikasi dengan menggunakan Integrating Sphere LMS9000B untuk mendapatkan data kuat cahaya, daya lampu dan efikasi yang akan dianalisis pada bagian pembahasan. Prosedur pengujian dilakukan berdasarkan SNI IEC/PAS 62612:2013. Terdapat 18 sampel yang diuji, dimana masing-masing sampel diuji dengan durasi 15 menit. Pemilihan durasi selama 15 menit ini bertujuan untuk mencapai kestabilan lumen atau kuat cahaya lampu setelah dinyalakan (proses stabilisasi termal). Proses pengujian pada penelitian ini dilakukan dengan tegangan input $230 \mathrm{~V}$. Suhu udara lingkungan 
pengujian dijaga $25 \pm 1{ }^{\circ} \mathrm{C}$ dan kelembaban relatif maksimum $65 \%$. Lampu yang akan diuji tidak perlu dituakan (ageing) terlebih dahulu.

\subsection{Metode Analisis Hasil Pengujian}

Hasil pengujian yang akan dianalisis pada penelitian ini adalah kuat cahaya, daya lampu dan efikasi. Data 18 sampel disajikan dalam grafik, dan grafik dibuat untuk setiap tipe lampu yang diuji. Selain itu juga disajikan data untuk setiap tipe lampu yang diuji. Hasil pengujian fluks atau kuat cahaya tidak boleh kurang dari $90 \%$ nilai fluks luminous pengenalnya, sedangkan hasil pengujian daya lampu tidak boleh melebihi $15 \%$ dari daya nominalnya (SNI IEC/PAS 62612:2013). Pada bagian analisis daya lampu, akan dibahas mengenai toleransi daya lampu pada saat beroperasi terhadap daya nominalnya. Data ini akan ditampilkan dalam bentuk grafik perbandingan.

\subsection{Jumlah Sampel}

Jumlah sampel yang digunakan pada pengujian ini sebanyak 18 buah lampu dari 6 jenis yang berbeda. Keenam jenis lampu tersebut selanjutnya disebut Tipe A, Tipe B, Tipe C, Tipe $D$, Tipe $E$ dan Tipe $F$. Jenis lampu yang digunakan terangkum dalam Tabel 2.

Tabel 2 Sampel pengujian lampu LED Tube

\begin{tabular}{|c|c|c|c|}
\hline No & Sampel & Jenis Lampu & Tipe \\
\hline 1 & Lampu 1 & Philips 8 W & \multirow{3}{*}{ Tipe A } \\
\hline 2 & Lampu 2 & Philips 8 W & \\
\hline 3 & Lampu 3 & Philips 8 W & \\
\hline 4 & Lampu 4 & Miyalux $9 \mathrm{~W}-3000 \mathrm{~K}$ & \multirow{3}{*}{ Tipe B } \\
\hline 5 & Lampu 5 & Miyalux $9 \mathrm{~W}-3000 \mathrm{~K}$ & \\
\hline 6 & Lampu 6 & Miyalux $9 \mathrm{~W}-3000 \mathrm{~K}$ & \\
\hline 7 & Lampu 7 & Miyalux $9 \mathrm{~W}-6500 \mathrm{~K}$ & \multirow{3}{*}{ Tipe C } \\
\hline 8 & Lampu 8 & Miyalux $9 \mathrm{~W}-6500 \mathrm{~K}$ & \\
\hline 9 & Lampu 9 & Miyalux $9 \mathrm{~W}-6500 \mathrm{~K}$ & \\
\hline 10 & Lampu 10 & Philips 16 W & \multirow{3}{*}{ Tipe D } \\
\hline 11 & Lampu 11 & Philips 16 W & \\
\hline 12 & Lampu 12 & Philips $16 \mathrm{~W}$ & \\
\hline 13 & Lampu 13 & King Led $18 \mathrm{~W}$ & \multirow{3}{*}{ Tipe E } \\
\hline 14 & Lampu 14 & King Led $18 \mathrm{~W}$ & \\
\hline 15 & Lampu 15 & King Led $18 \mathrm{~W}$ & \\
\hline
\end{tabular}

\begin{tabular}{llll}
\hline No & Sampel & Jenis Lampu & Tipe \\
\cline { 1 - 3 } 16 & Lampu 16 & Miyalux 18 W & \\
\cline { 1 - 2 } 17 & Lampu 17 & Miyalux 18 W & \\
\cline { 1 - 2 } 18 & Lampu 18 & Miyalux 18 W & \\
\hline
\end{tabular}

\section{HASIL DAN PEMBAHASAN}

\subsection{Kuat Cahaya}

Kuat cahaya atau fluks cahaya dengan satuan lumen merupakan jumlah total cahaya yang dipancarkan oleh sumber cahaya, tanpa memperhatikan arah (Gordon, 2008), kuat cahaya ini menyatakan gelap terangnya cahaya. Lumen (Im) adalah satuan terang gelapnya cahaya, dimana semakin besar lumen maka semakin terang cahayanya. Lumen adalah kesetaraan fotometrik dari watt, yang memadukan respon mata "pengamat standar". 1 watt $=683$ lumen pada panjang gelombang 555 nm (Permata, G. D, 2015).

Hasil pengujian kuat cahaya pada penelitian ini menunjukkan bahwa kuat cahaya lampu dipengaruhi oleh daya lampu. Pada penelitian ini diperoleh hasil bahwa untuk sampel lampu Tipe $\mathrm{E}$ dan Tipe $\mathrm{F}$ yang memiliki daya nominal yang sama yaitu $18 \mathrm{~W}$, menunjukkan adanya perbedaan kuat cahaya yang cukup signifikan. Sampel lampu Tipe E menghasilkan kuat cahaya rata-rata sebesar 2.337 lumen, sedangkan sampel lampu Tipe $F$ menghasilkan kuat cahaya rata-rata sebesar 1.487 lumen. Perbedaan kuat cahaya yang dihasilkan pada tipe lampu dengan daya yang sama ini menunjukkan perbedaan kinerja masing-masing tipe lampu. Lampu dengan daya yang sama tetapi menghasilkan kuat cahaya yang lebih tinggi memiliki kinerja yang lebih baik.

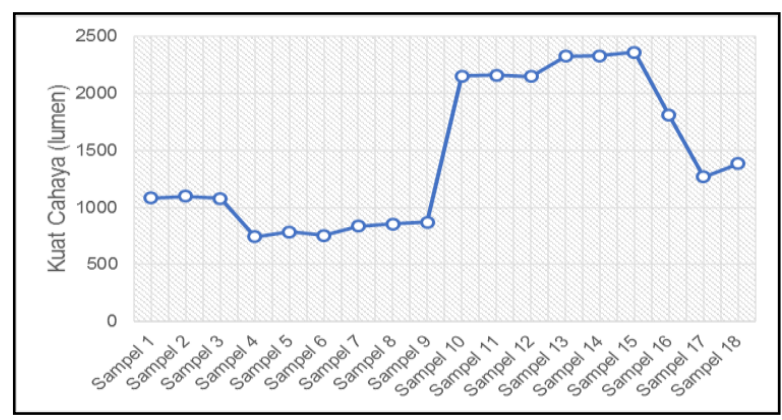

Gambar 5 Kuat cahaya pada setiap sampel yang diuji.

Grafik kuat cahaya pada setiap sampel lampu dan setiap tipe lampu masing-masing ditunjukkan oleh Gambar 5 dan Gambar 6. 


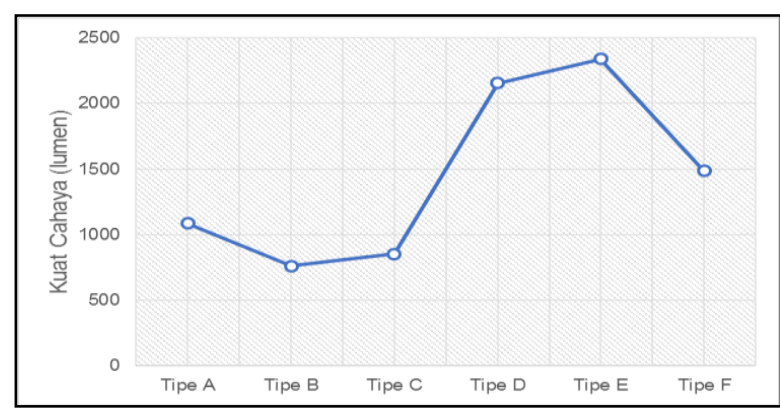

Gambar 6 Kuat cahaya rata-rata pada setiap tipe lampu.

\subsection{Daya Lampu}

Pada setiap produk elektronik, salah satunya lampu harus selalu tercantum informasi daya listrik yang merupakan besar energi listrik yang dihasilkan setiap detik. Daya listrik juga didefinisikan sebagai laju hantaran energi listrik dalam rangkaian listrik. Satuan SI daya listrik adalah watt yang menyatakan banyaknya tenaga listrik yang mengalir per satuan waktu (joule/detik).

Pada setiap sampel telah dilakukan pengukuran daya ketika lampu beroperasi. Daya yang dihasilkan dari pengukuran tersebut selanjutnya dibandingkan dengan daya nominal pada lampu. Perbandingan daya nominal dan daya pengukuran dari sampel tersebut ditunjukkan oleh Gambar 7 dan Gambar 8.

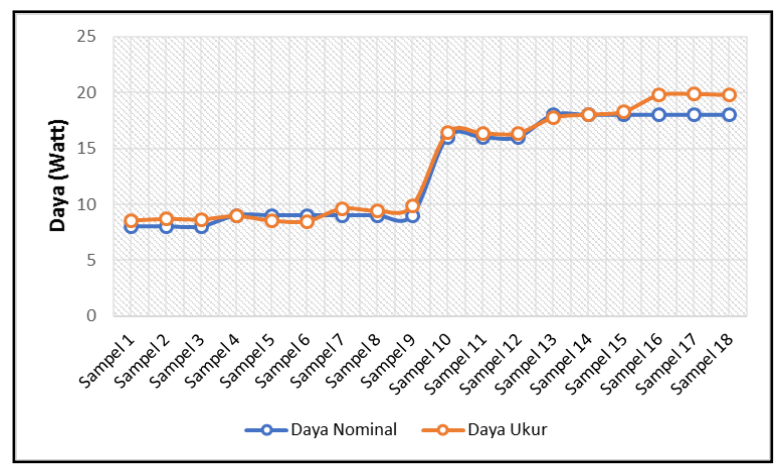

Gambar 7 Perbandingan daya nominal dengan daya rata-rata hasil pengukuran pada tiap sampel lampu.

Secara umum, daya operasi lampu pada penelitian ini lebih tinggi dari daya nominalnya, kecuali pada lampu Tipe B. Berdasarkan pada aturan dalam SNI IEC/PAS 62612:2013, toleransi daya lampu tidak boleh melebihi $15 \%$ dari daya nominalnya. Pada penelitian ini, setiap sampel lampu memiliki toleransi kurang dari $15 \%$. Dengan demikian, daya lampu sampel tersebut telah memenuhi ketentuan yang ditetapkan. Grafik toleransi lampu ditunjukkan pada Gambar 9.

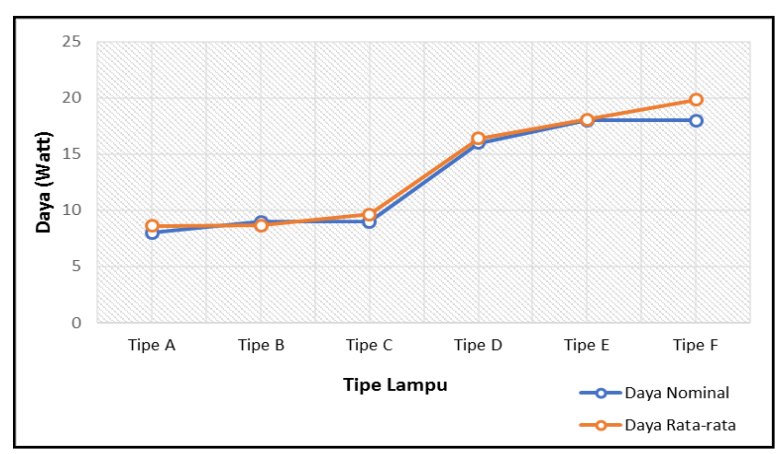

Gambar 8 Perbandingan daya nominal dengan daya rata-rata hasil pengukuran pada tiap tipe lampu.

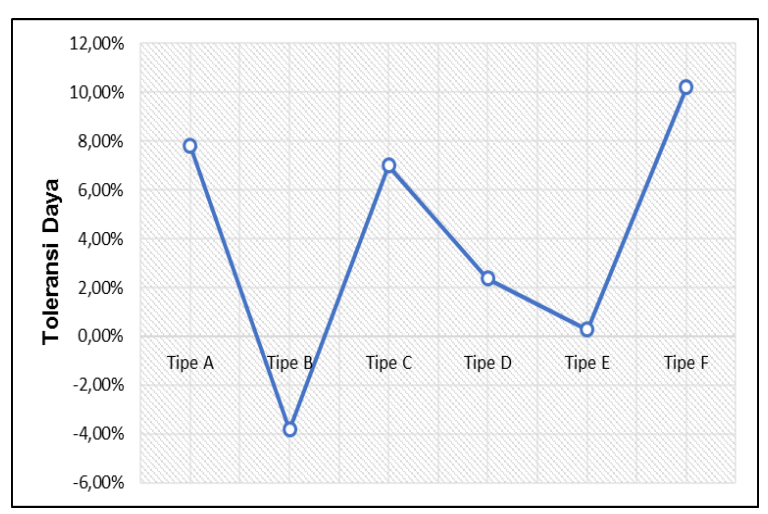

Gambar 9 Grafik toleransi daya lampu terhadap daya nominalnya pada setiap tipe lampu.

Berdasarkan Gambar 8 terlihat bahwa konsumsi daya lampu rata-rata pada saat beroperasi lebih tinggi $7,79 \%$ terhadap daya nominal untuk Tipe $A$, lebih rendah 3,81\% terhadap daya nominal untuk Tipe $\mathrm{B}$, lebih tinggi $7,00 \%$ terhadap daya nominal untuk Tipe C, lebih tinggi 2,37\% terhadap daya nominal untuk Tipe D, lebih tinggi $0,28 \%$ terhadap daya nominal untuk Tipe $E$ dan lebih tinggi 10,20\% terhadap daya nominal untuk Tipe F. Toleransi daya Tipe $B$ lebih rendah $3,81 \%$ artinya kebutuhan dayanya lebih sedikit dari spesifikasinya, sedangkan untuk tipe yang lain memerlukan daya yang lebih tinggi dibanding daya nominalnya. Namun, masih dalam batas yang diperbolehkan yaitu di bawah $15 \%$.

\subsection{Efikasi}

Efikasi ( $\eta$ ) [lumen/watt] adalah efisiensi sumber cahaya untuk menghasilkan cahaya terhadap daya listrik yang digunakan. Efikasi juga didefinisikan sebagai total flux cahaya yang dipancarkan oleh sumber cahaya dibagi dengan watt lampu; dinyatakan dalam lumen per watt (lumen/ watt). Tingkat efisiensi lampu dapat dilihat dari efikasinya (Permata, 2015). Hasil 
analisis efikasi pada penelitian ini ditunjukkan pada Gambar 10 dan Gambar 11.

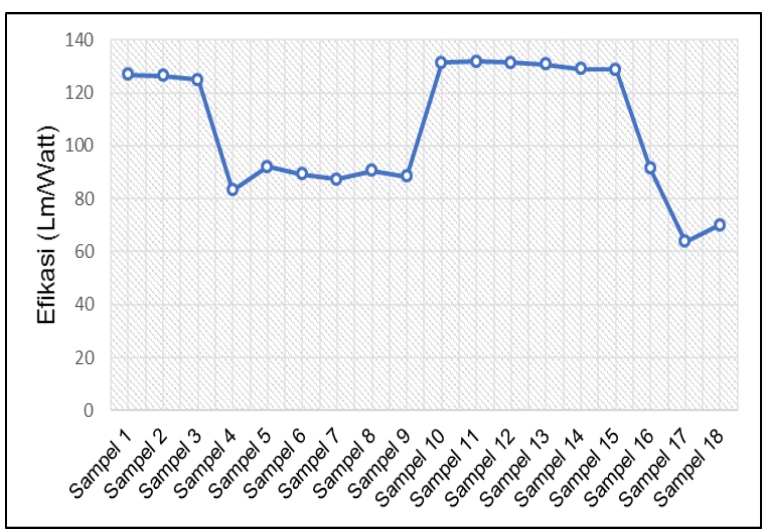

Gambar 10 Efikasi setiap sampel lampu yang diuji.

Gambar 10 menunjukkan efikasi pada setiap sampel yang diuji. Efikasi tertinggi pada sampel tersebut sebesar 132 Im/Watt, sedangkan efikasi terendah dari sampel tersebut sebesar $64 \mathrm{Im} /$ Watt.

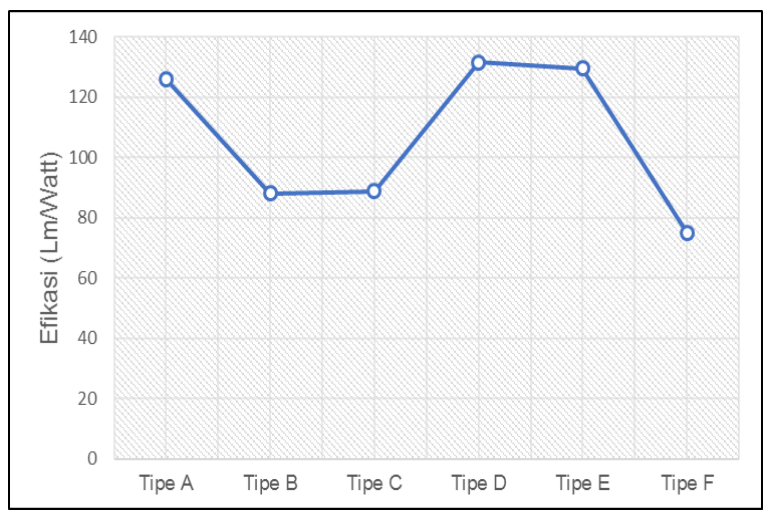

Gambar 11 Efikasi rata-rata pada setiap tipe lampu.

Gambar 11 menunjukkan efikasi pada setiap tipe lampu. Lampu Tipe $A$, Tipe $D$ dan Tipe $E$ memiliki yang tinggi yaitu di atas 120 Im/Watt, sedangkan lampu Tipe $B$, Tipe $C$ dan Tipe F memiliki efikasi di bawah $100 \mathrm{~lm} /$ Watt.

\section{KESIMPULAN}

Dari pengujian lampu LED tube sebanyak 18 buah, diperoleh hasil bahwa lampu Tipe $E$ menghasilkan kuat cahaya rata-rata sebesar 2.337 lumen, sedangkan sampel lampu Tipe $F$ menghasilkan kuat cahaya rata-rata sebesar 1.487 lumen. Kedua tipe lampu tersebut memiliki daya nominal yang sama. Perbedaan kuat cahaya yang dihasilkan pada tipe lampu dengan daya yang sama ini menunjukkan perbedaan kinerja masing-masing tipe lampu.

Daya lampu rata-rata pada saat beroperasi lebih tinggi 7,79 \% terhadap daya nominal untuk Tipe $A$, lebih rendah $3,81 \%$ terhadap daya nominal untuk Tipe $B$, lebih tinggi $7,00 \%$ terhadap daya nominal untuk Tipe C, lebih tinggi 2,37 \% terhadap daya nominal untuk Tipe D, lebih tinggi $0,28 \%$ terhadap daya nominal untuk Tipe $\mathrm{E}$ dan lebih tinggi 10,20\% terhadap daya nominal untuk Tipe F. Toleransi daya Tipe $B$ lebih rendah 3,81 \% artinya kebutuhan dayanya lebih sedikit dari spesifikasinya, sedangkan untuk tipe yang lain memerlukan daya yang lebih tinggi dibanding daya nominalnya. Namun, masih dalam batas yang diperbolehkan yaitu di bawah $15 \%$. Analisis efikasi lampu menunjukkan hasil bahwa efikasi tertinggi pada sampel tersebut sebesar 132 Im/Watt, sedangkan efikasi terendahnya sebesar 64 Im/Watt. Lampu Tipe A, Tipe D dan Tipe E memiliki yang tinggi yaitu di atas $120 \mathrm{~lm} /$ Watt, sedangkan lampu Tipe $B$, Tipe $C$ dan Tipe $F$ memiliki efikasi di bawah $100 \mathrm{~lm} /$ Watt.

\section{UCAPAN TERIMA KASIH}

Pada kesempatan ini penulis ingin mengucapkan terima kepada Manajemen Balai Besar Teknologi Konversi Energi (B2TKE) dan Badan Standardisasi Nasional (BSN) yang telah memberikan kesempatan untuk melaksakan penelitian ini dan mempublikasikan hasilnya, serta untuk rekanrekan personil Lab Permata yang telah banyak membantu kesuksesan penelitian ini.

\section{DAFTAR PUSTAKA}

Badan Standardisasi Nasional. (2011). SNI 046504-2001 Lampu swa-balast untuk pelayanan pencahayaan umumpersyaratan keselamatan

Badan Standardisasi Nasional. (2013). SNI IEC/PAS 62612:2013 Lampu LED swabalast untuk pelayanan pencahayaan umum - Persyaratan kinerja

Balai Besar Teknologi Energi (B2TE). (2012). "Perencanaan Efisiensi dan Elastisitas Energi 2012". Tangerang Selatan: Badan Pengkajian dan Penerapan Teknologi (BPPT).

Chang, Y. N., Cheng, H. L. \& Kuo, C. M. (2013). Design of High Efficiency Illumination for LED Lighting. International Journal of Photoenergy. Volume 2013, Article ID 471384, 8 pages 
Hao, H., Su, C., \& Li, C. (2015). LED Lighting System Reliability Modeling and Inference via Random Effects Gamma Process and Copula Function. International Journal of Photoenergy. Volume 2015, Article ID 243648, 8 pages.

International Electrotechnical Commission (IEC). (2011). IEC 62560:2011 Self-ballasted LED-lamps for general lighting services by voltage $>50 \mathrm{~V}$ - Safety specifications

International Electrotechnical Commission (IEC). (2013). IEC 62612:2013 Self-ballasted LED-lamps for general lighting services by voltage $>50 \mathrm{~V}$ - Safety specifications

Jianjie Fan, KC Yung, P Michael. (2012). Life time Estimationof High Power White LED using Degradation Data Driven Method" IEEE Transactions on Devices and Material Realibilit, Vol. 12, Issue 2, pp. 470-477. Sept. 2012.

Gordon, K. (2008) " Comparing White Light LEDs to Conventional Light Sources" Pacific Northwest National Laboratory. Energy Efficiency and Renewable energy, US Department of Energy. Juni 2008

Lincoln, D. The Performance of LEDs in LowVisibility Weather Conditions. IMSA Journal Page 34-36

Lingard, R. (2012). "Energy Efficiency of White LEDs" Pacific Northwest National Laboratory. Energy Efficiency and Renewable energy, US Department of Energy. Juni 2012
Lumerica. LED Technology. America's LED Lighting Solutions Company. Dapat diakses di http://www.lumerica.com/ledtechnology/

Navigant Consulting Inc. (2011). Energy Savings Estimates of Light Emitting Diodes in Niche Lighting Applications

Palaloi, S. (2009). Pemetaan Efikasi Lampu Swabalast untuk untuk Mendukung Penerapan SNI 04-6958-2003 Pada Lampu Hemat Energi. Jurnal Standardisasi, BSN. Vol. 11 No. $3 \mathrm{HIm}$. $185-191$.

Palaloi, S. (2015). Pengujian dan Analisis Umur Pakai Lampu Light Emitting Diode (LED) Swabalast untuk Pencahayaan Umum. Jurnal Energi dan Lingkungan Vol. 11, No. 1, Juni 2015 HIm. 17-22

Palaloi, S, Subhan Nafis, Sarimin. (2015). Kajian Tingkat Efikasi Lampu LED Swabalast untuk Pencahayaan Umum. Jurnal Ketenagalistrikan dan Energi Terbarukan Vol. 14, No. 1, Juni 2015 HIm. 1-14

Permata, G. D. (2015). Apa Itu Cahaya Lumens? Cahaya Candela ? dan Cahaya Lux?. Dapat diakses pada https://gilangdianpermata.wordpress.com /2015/11/06/apa-itu-cahaya-lumenscahaya-candela-dan-cahaya-lux/

Stevanus, D.Y., (2012). "Peluang Pemanfaatan Lampu LED Sebagai Lampu Penerangan Yang Hemat Energi". Program Sarjana Fakultas UI, Depok. 